Medical Research, Lilly Research Laboratories and the Josiah Macy, Jr., Foundation.

${ }^{1}$ Chambers, R., and Zweifach, B. W., J. Cell. Comp. Physiol., 15, 255 (1940). Zwelfach, B. W., Cold Spring Harbor Symposia on Quant. Biol., 8, $216(1940)$.

${ }^{2}$ Chambers, R., and Zweifach, B. W., Amer. J. Anat., 75, 173 (1944).

${ }^{3}$ Zweifach, B. W., Anat. Rec., 74, 475 (1939).

${ }^{4}$ Chambers, R., and Zweifach, B. W., Physiol. Rev., 27, 436 (1947).

${ }^{5}$ Chambers, R., Ann. N.Y. Acad. Sci., 49, 549 (1948).

- Zweifach, B. W., Lowenstein, B. E., and Chambers, R., Amer. J. Physiol., 142, 80 (1944).

' Zweifach, B. W., Lee, R. E., Hyman, C., and Chambers, R., Ann. Surg., 120, 232 (1944).

${ }^{8}$ Chambers, R., Zweifach, B. W., Lowenstein, B. E., and Lee, R. E., Proc. Soc. Exper. Biol. Med., 56, 127 (1944). Chambers, R., and Zweifach, B. W., Amer. J. Physiol., 150, 239 (1947).

${ }^{9}$ Chambers, R., Zweifach, B. W., and Lowenstein, B. E., Amer. $J$. Physiol.,139, 123 (1943). Zweifach, B. W., Abell, R. G., Chambers, R., and Clowes, G. H. A., Surg. Gynec. and Obst., 80, 593 (1945).

${ }^{10} \mathrm{Zweifach}$, B. W., "Evaluation of Therapy during Irreversible Hemorrhagic Shock on Basis of Changes in Omental Circulation" (in the press).

\section{SCIENTIFIC INSTRUMENTS AT THE COPENHAGEN EXHIBITION}

$I^{\mathrm{T}}$

was appropriate that the conclusion of an Anglo1 Danish trade agreement should have been followed. by the exhibition of the products of British industry, which took place in Copenhagen during September 18October 2. The Danes were thus able to assess for themselves the variety and quality of the manufactures which would be entering their country, in accordance with the terms of the trade agreement, while British exhibitors and visitors were enabled to sample far more freely than has been possible in Great Britain during recent years the Danish produce which was the subject of the converse part of the agreement. One abiding impression of the exhibition is the happy and almost festive atmosphere in which it was staged. Welcome was in the air at Copenhagen -being British was a passport to goodwill. We, on our side, contributed an exhibition of the products of our industry and added for good measure a visit by a contingent of our naval forces, the picturesqueness of the Gordon Highlanders, the spectacle of jetplanes in full flight, and the two-decked utility of British buses. The Danes responded with unlimited enthusiasm, courtesy and hospitality.

The exhibition was spread over a number of buildings in the city, and in one of them, the Gutenberghus, two floors were occupied by a display of scientific instruments. This exhibit took place under the ægis of the Scientific Instrument Manufacturers' Association of Great Britain and included the products of forty British scientific instrument firms. The first comment on this exhibit must not be in respect of the instruments themselves but of the unique and most attractive eatalogue-brochure which was produced for the occasion. This brochure took the form of a series of biographies of the exhibiting firms, the types of instruments being produced by any one firm being indicated in the margin, and the illustrations covered one outstanding product of each firm. One gathers from reading this brochure that any British scientific instrument firm celebrating its jubilee is in the 'young person' class of the industry ; a firm which can point to a century of activity may lay claim to some measure of maturity. The really firmly established have their origins in the eighteenth or even the seventeenth centuries! The remarkable contribution to the advancement of knowledge made by men of science in Great Britain during the era of modern seience has created a continuous demand for the manufacture of scientific instruments as aids to experimentation, and the fulfilment of this demand has meant that scientific instrument manufacture has been a lively activity in Great Britain certainly for three centuries. This fact is worth mentioning for two reasons. On one hand, it has been suggested, and in fact in some quarters assumed, that the traditional home of scientific instrument-making was elsewhere than in Britain. On the other hand, somewhat illogically, instrument manufacture in Great Britain has been eriticized on the grounds that it is saturated with tradition and that it has been slow in keeping abreast of modern requirements. The evidence contained in the brochure refutes the one suggestion, and the actual exhibition of instruments at Copenhagen provided a visual demonstration that, whatever truth there may have been at one time in the criticisms of the design and utility of British scientific instruments, such criticisms are no longer valid.

Conversations with those responsible for science and technology in Denmark made it abundantly clear that in the past the term 'scientific instrument' has been synonymous, so far as they were concerned, with 'German scientific instrument'. Very justly they held German scientific instruments in the highest regard, and both their interest in and knowledge of instruments emanating from other countries were practically negligible. It was, therefore, most heartening to hear these same people express considerable astonishment at the range of British instruments exhibited at Copenhagen and to receive their unqualified admiration of the design and quality of the instruments. It would be foolish to decry the excellence of instruments made elsewhere than in Britain. An exhibition such as that held in Copenhagen does, however, make it evident that we shall be carrying our national diffidence of self-advertisement too far if we do not pay tribute to the equal excellence of our own.

The first impression gained by a general survey of the instruments which were shown was that we have travelled a long way since the scientific instrument was, in the main, a tool of the scientific laboratory. One of the exhibits which excited very great interest was a radar equipment, by means of which a display was presented on a cathode-ray tube of the contours - church spires, main streets, harbour installations - of the city of Copenhagen. The home of such an instrument is the bridge of a ship, and the conditions under which it would be of most use are the very antithesis of those to be found in a laboratory. The main use of many of the instruments of greatest precision is in the street or the open country on one hand, or as an attachment to a machine tool on the other. This ubiquity of use, while in no way diminishing the importance of the achievement of the highest accuracy of measurement, has required that the modern scientific instrument shall be characterized by simplicity of operation and robustness in use. A comparison of the instruments shown at an exhibition twenty-five years ago and those recently displayed at Copenhagen would clearly indicate both the revolution and design which has been necessitated by the large extension of the use of instruments, and the remarkable evolution of entirely new types of instruments which has occurred during the last generation. The new principle incorporated in phase-contrast microscopy makes possible 
the observation of a wealth of detail within the confines of what were formerly merely nebulous out. lines. Incidentally, it has set the microscopist a pretty problem in interpretation. Electronic timing devices have made the pendulum appear a slow and cumbrous thing. The modern spectrograph, a most important industrial tool, has the lines of a gun turret rather than of a delicate scientific instrument. Any exhibition of modern scientific instruments provides both a survey of the growth of scientific knowledge and an indication of the extent to which science has intruded into every sphere of human activity.

The final word on the exhibition of scientific instruments at Copenhagen should be one of congratulation to British scientific instrument manufacturers, who in the short period of three years, after a long period of complete preoccupation with the production of instruments for military purposes, have most successfully reverted to their normal and natural activities. They have done this so completely, and in spite of the abnormal difficulties of the post-war years, that they are now able to meet the scientific, civil and industrial demands for instruments more abundantly than ever before in their history.

\section{INTERNATIONAL UNION OF CRYSTALLOGRAPHY}

$\mathrm{T}$ HE first meeting of the International Union of Crystallography, which was held at Harvard University during July 28-August 3, provided an opportunity for the presentation of papers on many research projects that are being carried out in different parts of the world. More than seventy such papers were read, and there were many detailed discussions.

Some of the sessions-for example, those on "Alloy Phase Structures" and "Proteins and Related Structures"-were held at the same time, and it was therefore not possible for a single observer to attend all of them and so to present an account of the whole conference. Since, in addition, the collection of abstracts alone would occupy more space than could be allowed for this article, it has been decided to describe the work relating to a few topics only. This, unfortunately, means that many papers will not be mentioned at all ; but it should be understood that the papers chosen for mention are not necessarily the most important, but are those that the present writer feels competent to knit into a coherent scheme.

It is inevitable that comparison should be made between the states of progress in the various countries represented at the Congress. In the thirty-six years since X-ray diffraction was discovered, many sub. divisions of the subject have arisen, and it is interesting to see how these have differently attracted different nationalities. It is, of course, undesirable that some branches of the subject should be ignored in any one country, and, by and large, this has not happened in the countries of major scientific importance; only at such international conferences does any unevenness become apparent. Conversely, contacts made at these conferences should encourage people, perhaps subconsciously, to fill up any gaps that may exist.

These observations were well illustrated by the papers presented at the conference; but unfortunately the comparison can be made only between the United States and Great Britain; the latter had by far the largest foreign delegation and provided about one third of the papers read at the conference, while other countries-India, Canada, Sweden, Holland and Germany-provided only one tenth between them.

\section{Instruments and Instrumentation}

The session on instruments was almost entirely American, and this preponderance was evident also in the apparatus that was exhibited. It may be argued that this was naturally so since the conference was held in the United States, but to the writer it did not seem that American superiority was too strongly emphasized; there was some British apparatus on view, and the only important omission was that of demountable X-ray tubes-otherwise all the recent developments were American.

For example, probably the most important recent advance in X-ray analysis is the introduction of Geiger counters for measuring intensities; this may ultimately release X-ray workers from the tyranny of the photographic film. Geiger-counter spectrometers are being made both by Philips Laboratories and the General Electric X-ray Corporation in America, whereas in Great Britain the author is aware of their existence only in more primitive form in certain laboratories. On the other hand, the American apparatus is directed toward the measurement of powder patterns, and, important as this measurement may be for industrial use, it has less theoretical importance than the study of single crystals. It is probable that this latter aspect is as far advanced in Great Britain as in America, but, in general, Geiger-counter apparatus is far more widely used in the United States.

As another example, Great Britain has produced nothing to compare with Buerger's precession goniometer. This instrument gives an undistorted repro. duction of a section of the reciprocal lattice and is proving invaluable in the study of crystals with large unit cells. It is true that the indexing of photographs is not a limiting factor in the determ. ination of crystal structures, but any aid to the shortening of this rather laborious operation must be welcomed and may even make practicable certain researches that are at present just outside the bounds of possibility.

In methods of Fourier synthesis, practice in the two countries is at present more or less the same; punched-card machines are greatly used by laboratories that have access to them, and printed strips, with calculating machines, are used by the less fortunate. But this balance is likely to be altered when the electronic machine at the Alabama Poly. technic Institute is completed; this machine should enable a complete two-dimensional Fourier synthesis to be presented instantaneously as an image on a fluorescent screen. With this instrument the major part of the operation will be the setting up of the coefficients; but, once these are set, changes in sign of certain coefficients can easily be introduced. It is possible that this instrument will make practicable the trial-and-error Fourier methods that have so often been suggested but never used.

Two other lines of progress must also be mentioned although they are not concerned with X-rays, namely, electron microscopy and neutron diffraction. Dr. R. W. G. Wyckoff showed electron micrographs of crystals in which individual molecules appeared 